\title{
Concoct Citrus Waste based Extruded Snacks: Optimizing Process Conditions Using Response Surface Methodology (RSM) and Delving Extrudate Attributes
}

\author{
Himanshu Prabhakar*, Shruti Sharma, Pushpinder Singh Ranote, \\ Baljit Singh and Savita Sharma
}
Department of Food Science and Technology, Punjab Agricultural University, Ludhiana 141004, Punjab, India
*Corresponding author

\begin{tabular}{|c|c|}
\hline & A B S T R A C T \\
\hline & $\begin{array}{l}\text { Kinnow, a citrus fruit associated with orange family, is a prominent grown fruit in India } \\
\text { and generates significant amount of waste when processed. Present study was undertaken }\end{array}$ \\
\hline Keywords & $\begin{array}{l}\text { to utilize kinnow waste (pomace) as an ingredient in extruded snacks. Dried kinnow } \\
\text { pomace at the level of } 2 \% \text { was added in the formulation mix along with salt }(2 \%) \text { and spice }\end{array}$ \\
\hline $\begin{array}{l}\text { Kinnow, Waste, } \\
\text { Pomace, Extrusion, } \\
\text { Optimization, RSM. }\end{array}$ & $\begin{array}{l}\text { mix }(1.3 \%) \text { and optimization of rice-kinnow pomace snack was done using Response } \\
\text { Surface Methodology (RSM). Central Composite Rotatable Design (CCRD) was used to }\end{array}$ \\
\hline Article Info & $\begin{array}{l}\text { study the effect of with independent variables viz. moisture content }(12-18 \%) \text {, screw speed } \\
(400-550 \mathrm{rpm}) \text { and die temperature }\left(120-180^{\circ} \mathrm{C}\right) \text {. The product responses viz. expansion }\end{array}$ \\
\hline $\begin{array}{l}\text { Accepted: } \\
\text { 04 September } 2017 \\
\text { Available Online: } \\
\text { 10 November } 2017\end{array}$ & $\begin{array}{l}\text { ratio (ER), bulk density (BD), water absorption (WAI) and solubility (WSI) indices, } \\
\text { hardness and overall acceptability were investigated. Results revealed that feed moisture } \\
\text { had the most significant effect on all product responses except overall acceptability. } \\
\text { Optimized extrusion parameters for preparation of snacks were } 16 \% \text { moisture, } 550 \mathrm{rpm} \\
\text { screw speed, } 131^{\circ} \mathrm{C} \text { temperature. }\end{array}$ \\
\hline
\end{tabular}

\section{Introduction}

Kinnow, a hybrid between king and willow mandarins (Citrus nobilis Lour $\times$ Citrus deliciosa Tenora) is one of the primal citrus fruit crops in Northern Indian states (Malla et al., 2015). India, with a production of 59.9 million tons annually estimating to be $24 \%$ in total world citrus production, retains fourth rank globally. Fruit peel and exhausted pulp (pomace) are the waste products of the kinnow processing industry and account for about 55-60\% of the fresh fruit weight (Malla et al., 2015). India generates about 7.8 million tons of citrus waste, where world average is about 119.7 million tons annually (NHB,
2011). Due to the lack of infrastructure for handling this huge quantity of biomass, disposal of kinnow waste remains a significant problem in the country. Such residue is generally disposed off in municipal bins and left untreated; this waste poses an economic liability to the fruit processors, as waste disposal is a growing anxiety.

The growing concern of citrus waste management has been addressed by studies conducted with different subject orientations. Majority of literature has been reported on conversion of citrus waste functional edible 
product(s) such as lab scale pectic enzyme (Garzón and Hours, 1992) and xanthan gum production (Bilanovic et al., 1994) and also employing citrus waste as a substrate for its hydrolization into limonene, ethanol and biogas (Lohrasbi et al., 2010). Despite of all the above mentioned studies propounded by different authors, there is another methodology by which citrus waste can be transformed into an edible product with succor of extrusion technology.

Extrusion cooking is a low-cost and efficient technology that utilizes high temperature, pressure and shear force to produce expanded, low-density snacks with unique textural properties. Extrusion of snack foods requires proximate check of numerous factors such as feed composition, particle size and moisture, barrel temperature, feed rate, die geometry, screw design and speed.

These process factors define the extent of macromolecular transformations occurring amid extrusion, thus impacting viscous dissipation in the extruder and subsequently, the product attributes of extrudates. Therefore, the study shall introduce the scope for production of such snacks on commercial scale, attempting to reduce and thereby, manage waste generated during citrus fruit production

The objective of this study was to investigate the possibility of using kinnow pomace as one of the ingredients in development of expanded snacks, study of process compatibility, optimization of the extrusion conditions and the effect of process variables vis-à-vis feed moisture content, screw speed and barrel temperature on the extrusion behavior and physical properties of kinnow pomace-rice flour based extrudates. For any extruded product, physical characteristics such as expansion, density and hardness are important parameters for the evaluation of consumer acceptability of the final product (Patil et al., 2007). The scope of the study was extended to examine the sensory properties of the selected extrudates in terms of overall acceptability.

\section{Materials and Methods}

\section{Materials}

Kinnow fruit was procured from local market, Ludhiana. Juice extraction and separation of pomace was succeeded by dehydration at $55 \pm 5^{\circ} \mathrm{C}$ using cabinet drier for 48 hours, followed by particle reduction and passed through $200 \mu \mathrm{m}$ sieves for further use in the study. Rice flour, salt and spices were also procured from local market.

Analyses of proximate composition (viz. moisture content, ash, protein, crude fibre, fat) of the raw materials and final product were performed according to the approved methods described in AOAC (2000).

\section{Feed preparation and optimization}

Preliminary trials were conducted to decide the levels of dried pomace in rice matrix, running the experiment with treatment ranging from 1 to $5 \%$. A semi-trained panel of 60 individuals, including students and faculty from the Department of Food Science and Technology, Punjab Agricultural University (India) evaluated the extruded snacks for appearance, color, texture and overall acceptability on a 9-point hedonic scale from 1 = dislike extremely to $9=$ like extremely) (Singh et al., 2013).

Product supplemented with $2 \%$ dried pomace was chosen and its proximate composition, physical and functional properties were studied. Experiments were conducted to determine proximate composition of dried pomace as well (Table 4). 


\section{Processing conditions: extruder}

Extrusion was performed on a co-rotating and intermeshing twin-screw extruder Model BC 21 (Clextral, Firminy, France). The barrel diameter and its length to diameter ratio (L/D) were $2.5 \mathrm{~mm}$ and 16:1, respectively. The temperature setting of four barrel zones was done as per experimental design where first three zones were maintained at $40^{\circ} \mathrm{C}, 70^{\circ} \mathrm{C}$ and $100^{\circ} \mathrm{C}$ respectively, whereas temperature at fourth zone was varied. The extruder had torque indicator exhibiting ratio of percentage of torque to the amperes used by motors and it also had die opening with diameter of $2 \mathrm{~mm}$. Raw material was metered into the extruder with a single screw volumetric feeder (D.S and M, Modena, Italy). The extruder was thoroughly calibrated with respect to the combinations of feed rate and screw speed to be used. The moisture content of feed was varied by injecting water (approximately $50^{\circ} \mathrm{C}$ ) into extruder with water pump. A variable speed die face cutter with four bladed knives was used to cut the extrudates (Singh et al., 2013).

\section{Product responses}

\section{SME (Specific mechanical energy)}

Specific mechanical energy (Wh/kg) was calculated from rated screw speed $(682 \mathrm{rpm})$, motor power rating $(8.5 \mathrm{~kW})$, actual screw speed, per cent motor torque, and mass flow rate $(\mathrm{kg} / \mathrm{h})$ using the following formula (Pansawat et al., 2008).

$\operatorname{SME}\left(\frac{W h}{\mathrm{~kg}}\right)=\frac{\text { Actual screw speed }(r p m) * \text { Percentmotor torque } * \text { Motor power rating }(W h)}{\text { Whe }}$

\section{Expansion ratio}

The ratio of the diameter of the extrudate and the diameter of the die was used to express the expansion ratio (ER) of the extrudate (Fan et al., 1996). The diameter of the extrudate was determined as the mean of random measurements made with a Vernier caliper. The extrudate expansion ratio was calculated as

$$
E R=\frac{\text { Diameter of ectrudate }(\mathrm{mm})}{\text { Diameter of die }(\mathrm{mm})}
$$

\section{Bulk density}

The density $(\mathrm{g} / \mathrm{cc})$ of the extruded snacks was measured by using a $100 \mathrm{ml}$ graduated cylinder using rapeseed displacement method. The volume of $20 \mathrm{~g}$ randomized samples was measured for each test. The ratio of sample weight and the replaced volume in the cylinder was calculated as density (Pan et al., 1998).

$B D=\frac{\text { Weight of extrudates }(g)}{\text { Volume of extrudates }(c c)}$

\section{Water Absorption Index (WAI)}

Water absorption index of the snacks was determined by method outlined by Anderson et al., (1969). The WAI measures the volume occupied by the granule or starch polymer after swelling in excess of water i.e. it pertains to degree or extent of gelatinization. The ground extrudates were suspended in distilled water at room temperature $\left(34^{\circ} \mathrm{C}\right)$ for 30 minutes, gently stirred during this period, and then centrifuged at $3000 \mathrm{rpm}$ for 10 minutes. The supernatant liquid was poured carefully into tared evaporating dish. The remaining gel was weighed and WAI was calculated as the grams of gel obtained per gram of solid.

WAI $=\frac{\text { Weight of sedimanets }(g)}{\text { Weight of dry solids }(g)}$

\section{Water Solubility Index (WSI)}

Water Solubility Index quantifies the released amount of polysaccharides from the granule 
on addition of surplus water. This property is in direct relation with the digestibility of food product. Low molecular weight polysaccharides formed during the process are assimilated inside the body promptly. The WSI is the weight of dry solids in the supernatant from the water absorption index test described above (Anderson et al., 1969) expressed as a percentage of the original weight of the sample.

WSI $(\%)=\frac{\text { Weight of dissolved solid in supernatant }}{\text { Weight of dry solids }} * 100$

\section{Hardness}

Textural quality of the snack samples was examined by using a TA-XT2i Texture Analyzer (Stable Microsystems, Surrey, UK). The compression probe $(50 \mathrm{~mm}$ diameter, aluminum cylinder) was used to measure the compression force required for sample breakage which indicates hardness. Testing conditions were $1.0 \mathrm{~mm} / \mathrm{s}$ pre-test speed, 2.0 $\mathrm{mm} / \mathrm{s}$ test speed, $10.0 \mathrm{~mm} / \mathrm{s}$ post test speed and $5 \mathrm{~mm}$ distance (Bourne 1978) and readings were taken in triplicates for each sample.

\section{Experimental design and data analysis}

The central composite rotatable design CCRD for the three independent variables was performed. The independent variables considered were moisture (x_1), screw speed (x_2) and barrel temperature (x_3). The independent variables and variation levels are shown in Table 1 . The levels of each variable were established on the basis of preliminary trials. The outline of experimental design with the actual level is presented in Table 1. The dependent process variables were SME, ER, BD, WSI, WAI, hardness and sensory based overall acceptability. RSM was utilized to delve the impact of extrusion conditions on the final product attributes and responses. The independent variable levels like feed moisture content (12-18\%), screw speed (400-550 rpm) and barrel temperature of the last zone (120$180^{\circ} \mathrm{C}$ ) considered for study were selected on the basis of preliminary trials. A rotatable, central composite design (Myers 1971) was employed to determine the extrusion conditions. The design required 20 experimental runs with eight factorial points, six star corner points and six center points. Experiments were randomized in order to minimize the systematic bias in observed responses due to extraneous factors. The individual effect of each variable and the effect of interaction in coded levels of variables were determined (Singh et al., 2013).

\section{Statistical analysis and optimization}

Responses obtained as a result of the proposed experimental design were subjected to regression analysis in order to assess the effects of moisture content, screw speed and barrel temperature. Second-order polynomial regression models were established for the dependent variables to fit experimental data for each response using statistical software Design-Expert 9.0.0 (Stat-Ease Inc., Minneapolis, MN).

$y_{i}=b_{0}+\sum_{i=1}^{a} b_{i} x_{i}+\sum_{i=1}^{a} b_{i i} x_{i}^{2}+\sum_{i=1}^{a} \sum_{i=1}^{a} b_{i j} x_{i} x_{j}$

Where $x_{-} \mathrm{i}(\mathrm{i}=1,2,3)$ are independent variables (moisture, screw speed and barrel temperature), respectively and b_0, b_i, b_ii and $b_{-} \mathrm{ij}$ are coefficient for intercept, linear, quadratic and interactive effects, respectively. Data analysis for each response was done by multiple regressions and statistical significance of each term was delved using analysis of variance (ANOVA). The adequacy of regression model was checked by correlation coefficients. The lack of fit test was used to judge the adequacy of model fit. To aid visualization of variation in responses 
with respect to processing variables, series of three-dimensional response surfaces plots were drawn. The samples were evaluated organoleptically for appearance, texture, flavor and overall acceptability by semitrained panel of 60 judges using 9-point hedonic scale (Yeh et al., 1998).

\section{Results and Discussion}

Table 1 represents the summary of mean value data of physical attribute of extrudates along with their standard deviations. ANOVA and Predicted vs. actual responses are summarized in Table 2 and 3. Models for all parameters were significant, and all the parameters were significantly affected by three factors taken i.e. feed moisture, screw speed and barrel temperature. None of the models showed significant lack of fit $(\mathrm{P}>$ 0.01), indicating that all the second-order polynomial models correlated well with the measured data. Adequate precision (signal to noise ratio) greater than 4 is desirable. All the parameters showed high adequate precision (Table 2).

Various physical and functional properties have been studied in different extruded products. Singh et al., (2013) studied SME, BD, WAI, WSI and hardness in potato based snacks. Altan et al., (2008a) studied expansion, BD, texture and color in barleygrape pomace based extruded snacks. Hagenimana et al., (2006) studied the effect of extrusion cooking on modified rice flour in terms of physical properties including WAI, WSI, ER, total color change and BD. Blend of green gram and rice flour was optimized and studied for physical parameters including ER, water holding capacity (WHC), peak shear stress and scanning electron microscopy (SEM) (Chakraborty and Banerjee, 2009). All of the studies mentioned above have shown a significant effect of process variables on physical properties.

\section{Specific mechanical energy}

Mathematical model was fitted to the experimental data using regression analysis. Equation for SME's predicted model in the form of coded values can be devised as:

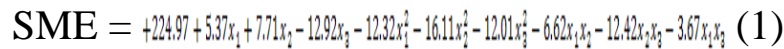

Specific mechanical energy (SME) refers to measure of energy exerting in extrusion system per unit mass in the form of work done by the motor. The measured SME in extrusion cooking of rice flour and pomace powder blends ranged from 162.51 to 229.38 Wh/kg (Table 1). An ANOVA was conducted to assess the significant effects of the independent variables on responses and which of the responses were significantly affected by the varying processing conditions. The analysis of variance (ANOVA) for SME of quadratic model (Eq. 1) is given in Table 2. The coefficient of variation (CV) was found to be $1.50 \%$ for SME. Very precise coefficient of determination $\left(\mathrm{R}^{2}\right)$ and adjusted $\mathrm{R}^{2}$ value of 0.9927 and 0.9861 respectively was obtained indicating acceptance of model in terms of SME.

Moisture (x_1) and screw speed (x_2) had highly significant positive linear effect while temperature (x_3) had a highly significant negative linear effect on specific mechanical energy. SME increased with increase in moisture. Similar results have been reported by Garber et al., (1997) in corn meal, Kannadhason et al., (2009) and Chevanan et al., (2008) in distiller's dried grains. This might be because of the fact that the increase in moisture content lead to decrease in temperature resulting in elevation in SME. With increase in screw speed, SME increased. Similar observations were recorded by Yeh and Jaw (1999) in rice extrudates. Increasing the screw speed lead to detraction in torque but the effect of increased screw speed was 
not compensated by it. Also, the effect of screw speed overpowered effect of viscosity thus increasing SME (Jin et al., 1994). It was observed that with increase in temperature, SME decreased and there are number of studies which are in agreement with this outcome namely Dogan \& Karwe (2003) in quinoa extrudates, Altan et al., (2008a) and Koksel et al., (2004) in barley based extrudates, Ryu \& Ng (2001) in wheat based extrudates and Pathania et al., (2013) in wheat, mung-bean and rice blend. Viscous dissipation abated with increase in temperature which lead to reduced SME (Altan et al., 2008b) (Chang et al., 1999) (Hsieh et al., 1989).

\section{Expansion Ratio (ER)}

Mathematical model was fitted to the experimental data using regression analysis. Equation for ER's predicted model in the form of coded values can be devised as:

$\mathrm{ER}=+3.24-0.063 x_{1}+0.12 x_{2}-0.010 x_{1}-0.38 x_{1} x_{2}-0.15 x_{2} x_{3}+0.056 x_{1} x_{1}$

The extruded product goes through transition resulting in product with altered texture and size while exiting the die because of the release of moisture, alleviation of forces and heat. The measured expansion in extrusion cooking of rice flour and pomace powder blend ranged from 2.71 to 3.94 (Table 1). ANOVA interprets a highly significant model $(\mathrm{P}<0.0001)$ with coefficient of determination $\left(\mathrm{R}^{2}\right)$ of 0.9650 and adjusted $\mathrm{R}^{2}$ value of 0.9489 with coefficient of variation $(\mathrm{CV})$ of $2.05 \%$. The analysis of variance (ANOVA) for expansion ratio of quadratic model (Eq. 2) is given in Table 2. $\mathrm{F}$ value for expansion ratio was significant $(\mathrm{P}<0.001)$ whereas lack-of fit was not significant $(\mathrm{P}>0.0595)$.

Screw speed $\left(x_{2}\right)$ exhibited a positive linear effect whereas moisture $\left(x_{1}\right)$ and temperature $\left(x_{a}\right)$ had significant negative linear effect (Fig.
1). Expansion ratio decreased with increase in moisture and similar results have been reported by Kumar et al., (2010) in rice based extrudates, Pathania et al., (2013) in wheat, mung-bean and rice blend and Ding et al., (2006) in rice based extrudtaes. With increase in moisture, dough elasticity and temperature decreased due to reduced friction between dough, screw and barrel which negatively impacted gelatizination resulting in reduced expansion. With increase in screw speed, expansion ratio increased. Perverse to it, observation promulgated that expansion ratio decreased with increase in temperature and similar results have been reported by Mendoca et al., (2000) in corn bran-corn meal blend, Altan et al., (2008a) in barley based extrudates and Yagci and Gogus (2009) in rice grit-wheat flour based extrudates. This might have occured because of defragmentation of starch at higher temperature obviating expansion in extrudates (Chakraborty and Banerjee 2007).

\section{Bulk density}

Mathematical model was fitted to the experimental data using regression analysis. Equation for BD's predicted model in the form of coded values can be devised as:

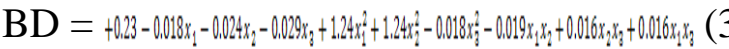

Bulk density is basically a measure of outward expansion of an extrudate in all directions unlike expansion ratio which considers only the perpendicular direction to extrudate flow. The measured bulk density in extrusion cooking of rice flour and pomace powder blends ranged from 0.12 to $0.29 \mathrm{~g} / \mathrm{cc}$ (Table 1). ANOVA interprets a highly significant model $(\mathrm{P}<0.0001)$ with coefficient of determination $\left(\mathrm{R}^{2}\right)$ of 0.9540 and adjusted $\mathrm{R}^{2}$ value of 0.9127 coefficient of variation (CV) of $5.88 \%$. The analysis of variance (ANOVA) for expansion ratio of quadratic 
model (Eq. 3) is given in Table 2. F value for bulk density was significant $(\mathrm{P}<0.001)$ whereas lack-of fit was not significant $(\mathrm{P}>$ 0.2030).

Moisture $\left(x_{1}\right), \quad$ screw speed $\left(x_{2}\right)$ and temperature $\left(x_{a}\right)$ had highly significant negative linear effect. Bulk density decreased with increase in moisture (Fig. 2). Similar results have been reported by Asare et al., (2004) in rice-cowpea-groundnut blend, Baik et al., (2004) in rice-chickpea blend and Ding et al., (2006) in rice based extrudates. Increase in moisture content mitigated the viscosity of product resulting in remission in SME but presence of humectants such as salt and spices competed with rice matrix and absorbed available moisture resulting in increased flow and reduced bulk density.

Increasing screw speed resulted in decrease in bulk density. Similar results were observed by Chevanan et al., (2008) in distiller's dried grains, Kumar et al., (2010) in rice extrudates and Hagenimana et al., (2006) in rice flour. Bulk density decreased at higher screw speed because of consolidation of pressure due to revolving screw inside barrel. As the product started exiting the die, pressure gradient gave rise to puffed and expanded product with low density. Bulk density decreased with increase in temperature as observed by Kumar et al., (2010) in rice based extrudates, Altan et al., (2008a) in grape pomace- barley blend, Altan et al., (2008b) in tomato pomace-barley blend, Case et al., (1992) in wheat-corn flour based extrudates and Mercier and Feillet (1975) in cereal based extrudates. Kokesel et al., (2004) explained this phenomenon as increase in temperature gave a higher potential energy for the flash-off of superheated water from extrudates as they left the die. As barrel temperature elevated, extrudates exiting die lost more moisture and became lighter in weight resulting in puffed product.

\section{Water Absorption Index (WAI)}

Mathematical model was fitted to the experimental data using regression analysis. Equation for WAI's predicted model in the form of coded values can be devised as:

$\mathrm{WAI}=+2.20+0.77 x_{1}+0.28 x_{2}+0.13 x_{\mathrm{a}}(4)$

WAI is basically a measure of capacity of starch granules to hold excess of water thus forming a gel. The measured WAI in extrusion cooking of rice flour and pomace powder blends ranged from 0.96 to $4.32 \mathrm{~g} / \mathrm{g}$ (Table 1). The analysis of variance (ANOVA) for WAI of quadratic model (Eq. 4) is given in Table 2. Regression model fitted to experimental results had coefficient of determination $\left(\mathrm{R}^{2}\right)$ adjusted $\mathrm{R}^{2} 0.6013$ and 0.5266 coefficient of variation $(\mathrm{CV})$ of 28.26 $\%$. $\mathrm{F}$ value for $\mathrm{SME}$ was significant $(\mathrm{P}=$ 0.0017) whereas lack-of fit was not significant $(\mathrm{P}>0.5453)$. Moisture $\left(x_{1}\right)$, screw speed $\left(x_{2}\right)$ and temperature $\left(x_{3}\right)$ had a highly significant positive linear effect on WAI. During extrusion process, it was observed that WAI increased with increase in moisture.

Similar results have been reported by Hagenimana et al., (2006) in rice flour, Chang et al., (1998) in jatoba flour-cassava starch blend, Baladran-Quintana et al., (1998) in white pinto bean meal based extrudates, Singh et al., (2007) in potato based snacks, Yagci and Gogus (2008) in rice grit-wheat flour based extrudates and Dogan and Karwe et al., (2003) in quinoa extract.

As temperature increased, protein denatured, starch got gelatinized and swelling of fiber occurred which, in moderate extrusion conditions, disrupted the molecular structure creating pores leading to penetration of water and thus expansion of extrudates (Ching et al., 1998). Increasing screw speed resulted in increase in WAI. 
Table.1 Effect of extrusion condition on process and product responses of pomace based rice extrudates

\begin{tabular}{|c|c|c|c|c|c|c|c|c|c|c|}
\hline \multirow[t]{2}{*}{ S.no. } & \multicolumn{3}{|c|}{ Extrusion Conditions } & \multicolumn{7}{|c|}{ Responses } \\
\hline & $\begin{array}{c}\text { A: Moisture } \\
(\%)\end{array}$ & $\begin{array}{c}\text { B:Screw } \\
\text { speed } \\
(\text { rpm })\end{array}$ & $\begin{array}{c}\text { C: } \\
\text { Temperature } \\
\left({ }^{\circ} \mathrm{C}\right)\end{array}$ & $\begin{array}{c}\text { SME } \\
(\mathbf{W h} / \mathbf{K g})\end{array}$ & $\begin{array}{c}\text { Expansion } \\
\text { ratio }\end{array}$ & $\begin{array}{c}\text { Density } \\
\text { (g/cc) }\end{array}$ & $\begin{array}{l}\text { WAI } \\
(\mathrm{g} / \mathrm{g})\end{array}$ & $\begin{array}{l}\text { WSI } \\
(\%)\end{array}$ & $\begin{array}{l}\text { Hardness } \\
\text { (N) }\end{array}$ & $\begin{array}{c}\text { Overall } \\
\text { acceptability }\end{array}$ \\
\hline 1 & $14(-1)$ & $400(-1)$ & $130(-1)$ & 193.94 & 3.27 & 0.29 & 3.31 & 55.36 & 10.39 & 6.79 \\
\hline 2 & $14(-1)$ & $400(-1)$ & $170( \pm 1)$ & 181.19 & 3.49 & 0.25 & 1.31 & 72.41 & 6.81 & 6.78 \\
\hline 3 & $14(-1)$ & $550( \pm 1)$ & $130(-1)$ & 185.51 & 3.70 & 0.18 & 2.66 & 58.76 & 18.23 & 7.17 \\
\hline 4 & $14(-1)$ & $550( \pm 1)$ & $170( \pm 1)$ & 229.38 & 3.23 & 0.23 & 0.96 & 74.36 & 10.60 & 7.66 \\
\hline 5 & $18( \pm 1)$ & $400(-1)$ & $130(-1)$ & 223.44 & 3.01 & 0.19 & 3.52 & 48.64 & 7.75 & 6.83 \\
\hline 6 & $18( \pm 1)$ & $400(-1)$ & $170( \pm 1)$ & 226.56 & 3.24 & 0.24 & 1.96 & 70.69 & 10.67 & 7.71 \\
\hline 7 & $18( \pm 1)$ & $550( \pm 1)$ & $130(-1)$ & 225.38 & 3.22 & 0.23 & 1.01 & 62.35 & 10.61 & 7.65 \\
\hline 8 & $18( \pm 1)$ & $550( \pm 1)$ & $170( \pm 1)$ & 163.06 & 2.81 & 0.12 & 4.32 & 39.34 & 14.79 & 7.02 \\
\hline 9 & $12.6(-1.682)$ & $475(0)$ & $150(0)$ & 223.68 & 3.25 & 0.22 & 2.27 & 74.12 & 10.65 & 7.62 \\
\hline 10 & $19.4( \pm 1.682)$ & $475(0)$ & $150(0)$ & 172.81 & 3.53 & 0.25 & 1.81 & 66.96 & 5.85 & 6.24 \\
\hline 11 & $16(0)$ & $349(-1.682)$ & $150(0)$ & 189.38 & 3.55 & 0.19 & 2.86 & 50.11 & 7.81 & 7.45 \\
\hline 12 & $16(0)$ & $601( \pm 1.682)$ & $150(0)$ & 216.25 & 3.94 & 0.23 & 1.84 & 66.88 & 7.15 & 7.53 \\
\hline 13 & $16(0)$ & $475(0)$ & $161(-1.682)$ & 209.88 & 3.28 & 0.23 & 1.42 & 69.07 & 7.82 & 7.13 \\
\hline 14 & $16(0)$ & $475(0)$ & $203( \pm 1.682)$ & 162.51 & 2.71 & 0.28 & 1.52 & 67.45 & 10.35 & 7.21 \\
\hline 15 & $16(0)$ & $475(0)$ & $150(0)$ & 224.69 & 3.25 & 0.23 & 1.54 & 67.77 & 10.62 & 7.69 \\
\hline 16 & $16(0)$ & $475(0)$ & $150(0)$ & 220.63 & 3.15 & 0.25 & 2.42 & 60.34 & 10.61 & 7.80 \\
\hline 17 & $16(0)$ & $475(0)$ & $150(0)$ & 166.69 & 3.03 & 0.28 & 1.94 & 64.41 & 13.39 & 7.24 \\
\hline 18 & $16(0)$ & $475(0)$ & $150(0)$ & 169.36 & 3.19 & 0.13 & 2.29 & 60.55 & 13.38 & 6.29 \\
\hline 19 & $16(0)$ & $475(0)$ & $150(0)$ & 196.31 & 3.15 & 0.22 & 3.43 & 49.66 & 14.39 & 6.53 \\
\hline 20 & $16(0)$ & $475(0)$ & $150(0)$ & 166.51 & 2.90 & 0.21 & 1.71 & 67.52 & 10.05 & 6.16 \\
\hline
\end{tabular}


Table.2 ANOVA for the fit of experimanetal data to RSM

\begin{tabular}{|c|c|c|c|c|c|c|c|}
\hline \multirow[t]{2}{*}{ Regression } & \multicolumn{7}{|l|}{$\begin{array}{l}\text { Sum of } \\
\text { squares }\end{array}$} \\
\hline & SME & Expansion & $\begin{array}{l}\text { Bulk } \\
\text { Density }\end{array}$ & WAI & WSI & Hardness & $\begin{array}{l}\text { Overall } \\
\text { acceptability }\end{array}$ \\
\hline $\begin{array}{l}\text { Adequate } \\
\text { precision }\end{array}$ & 30.230 & 32.847 & 18.972 & 9.247 & 9.451 & 467.961 & 20.438 \\
\hline R square & 0.9927 & 0.9650 & 0.9540 & 0.6013 & 0.8686 & 0.9999 & 0.9798 \\
\hline Adjusted & 0.9861 & 0.9489 & 0.9127 & 0.5266 & 0.7503 & 0.9998 & 0.9616 \\
\hline \multicolumn{8}{|l|}{ R square } \\
\hline C V $(\%)$ & 1.50 & 2.05 & 5.88 & 28.26 & 7.64 & 0.42 & 1.46 \\
\hline Lack of fit & $0.4769 \mathrm{NS}$ & $0.0595 \mathrm{NS}$ & $0.2030 \mathrm{NS}$ & $0.5453 \mathrm{NS}$ & $0.8984 \mathrm{NS}$ & $0.0817 \mathrm{NS}$ & $0.0586 \mathrm{NS}$ \\
\hline
\end{tabular}

NS =non-significant

Table.3 Predicted responses vs. actual response

\begin{tabular}{ccccccc}
\hline \multicolumn{7}{c}{ Responses } \\
\hline Values & ER & BD (g/cc) & WAI (g/g) & WSI (\%) & Hardness (N) & Overall acceptability \\
\hline Predicted & 3.25 & 0.23 & 2.21 & 68.33 & 8.8 & 7.69 \\
Actual & 3.4 & 0.22 & 2.19 & 68.5 & 8.54 & 7.65 \\
Variation (\%) & 4.61 & 4.54 & 0.91 & 3.84 & 3.04 & 0.52
\end{tabular}

Table.4 Proximate composition $(n=3)$

\begin{tabular}{cccccc}
\hline Material & $\begin{array}{c}\text { Moisture } \\
(\boldsymbol{\%})\end{array}$ & $\begin{array}{c}\text { Crude protein } \\
(\boldsymbol{\%})\end{array}$ & $\begin{array}{c}\text { Fat } \\
(\boldsymbol{\%})\end{array}$ & $\begin{array}{c}\text { Ash } \\
(\boldsymbol{\%})\end{array}$ & $\begin{array}{c}\text { Crude Fibre } \\
(\boldsymbol{\%})\end{array}$ \\
\hline Rice flour & $10.78 \pm 0.25$ & $7.75 \pm 0.11$ & $0.51 \pm 0.13$ & $1.78 \pm 0.15$ & $1.74 \pm 0.27$ \\
Dried pomace & $2.91 \pm 0.24$ & $4.88 \pm 0.09$ & $2.18 \pm 0.11$ & $3.47 \pm 0.11$ & $9.89 \pm 0.30$ \\
Pomace expanded snacks & $2.91 \pm 0.21$ & $9.59 \pm 0.15$ & $0.22 \pm 0.15$ & $3.26 \pm 0.16$ & $2.12 \pm 0.25$
\end{tabular}

Where $n=$ number of replicates kept for analysis 
Fig.1 Effect of moisture and screw speed on the Expansion Ratio (ER)

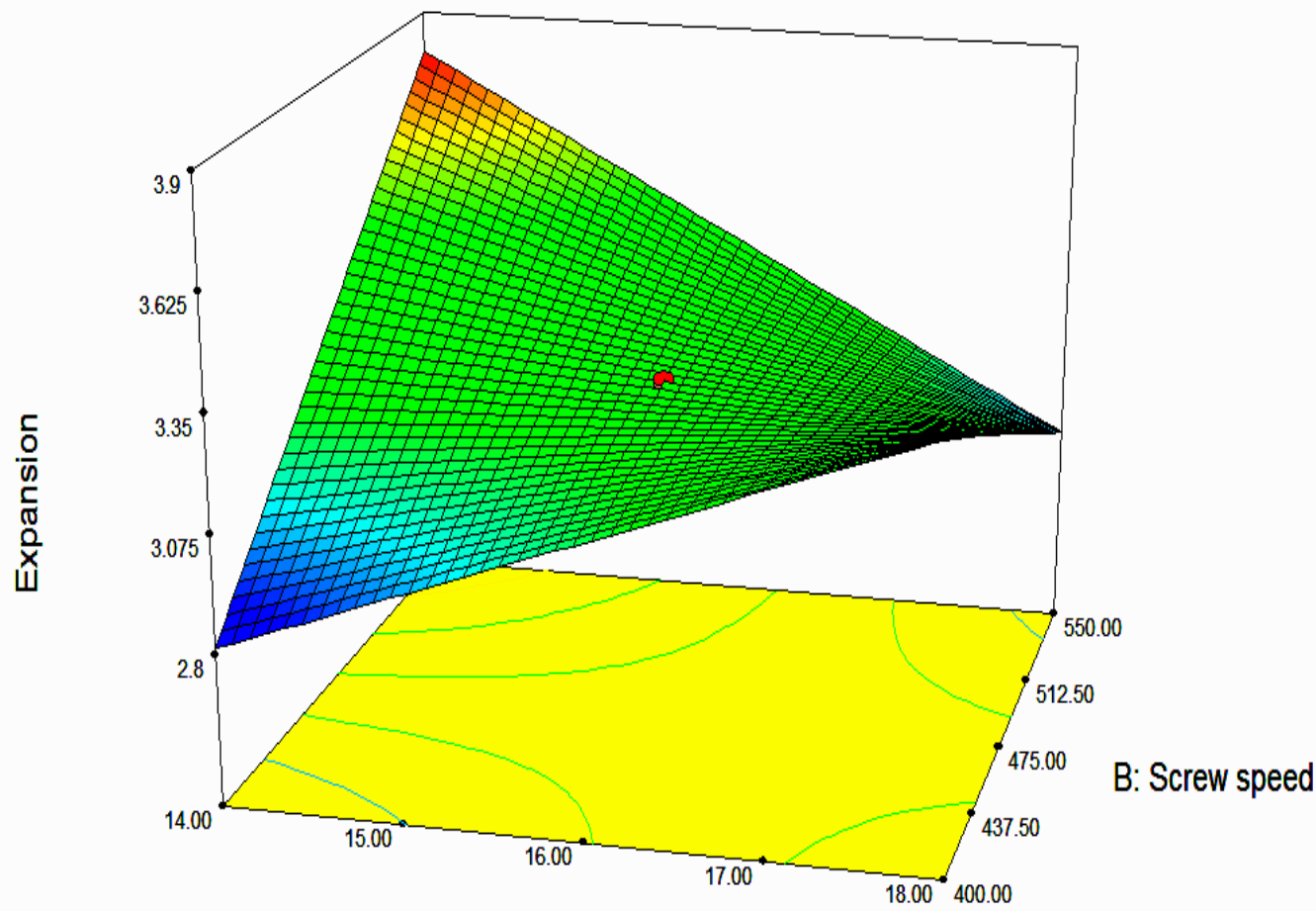

A: Moisture

Fig.2 Effect of moisture and screw speed on the Bulk Density (BD)

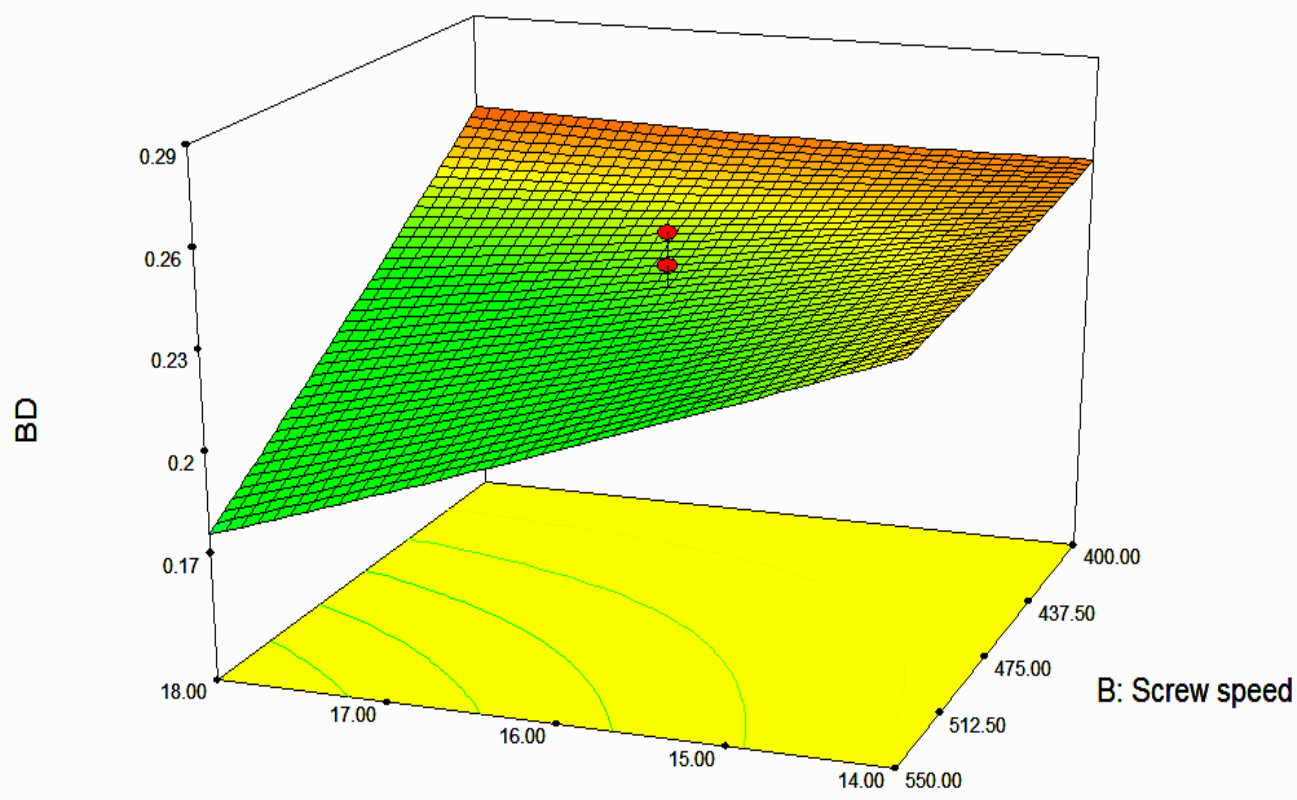

A: Moisture 
Fig.3 Desirability function graph

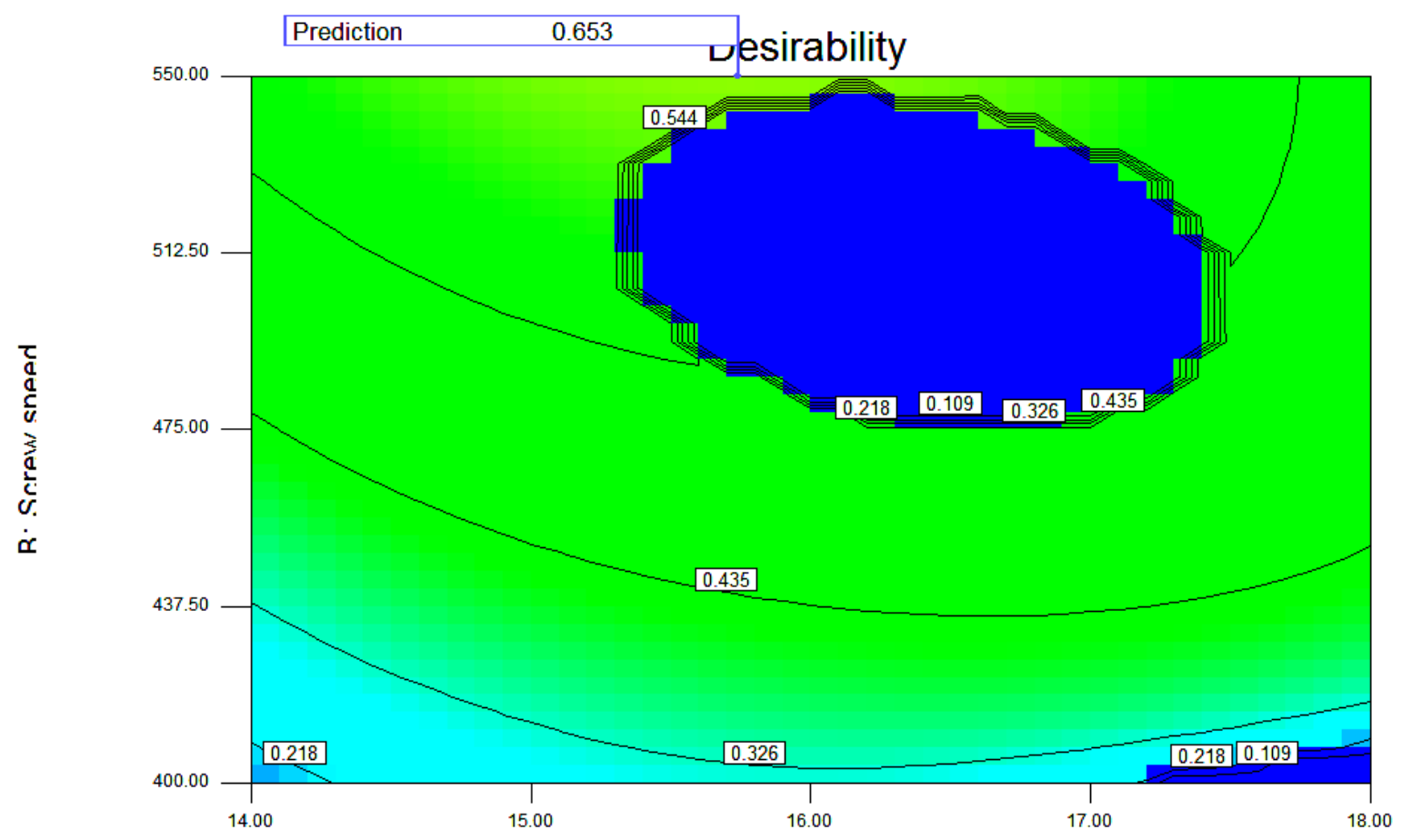

A: Moisture

Similar results were observed by Pathania et al., (2013) in wheat, mung-bean and rice blend. Altan et al., (2008a) reported that presence of fibre altered water uptake behavior of whole matrix due to which, increase in screw speed lead to increase in WAI. Also, there is a possibility that screw speed resulted in structural modification in pomace powder and spice mix during extrusion process, which was incorporated along with rice flour. WAI increased with increase in temperature. Similar results were observed by Hagenimana et al., (2006) and Kumar et al., (2010) in rice based extrudate, Dogan \& Karwe (2003) in quinoa extrudate, Pathania et al., (2013) in wheat, mung-bean and rice blend and Singh et al., (2007) in potato based extrudates. There was a rapid increase of WAI at lower temperatures because of availability of more undamaged polymer chains as well as hydrophilic groups for binding more water, which resulted in higher values of WAI (Gomez and Aguilera 1983; Guha et al., 1997).

\section{Water Solubility Index (WSI)}

Mathematical model was fitted to the experimental data using regression analysis. Equation for WSI's predicted model in the form of coded values can be devised as:

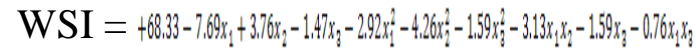

Water Solubility Index (WSI) gives information about degradation of starch granules. The measured expansion in extrusion cooking of rice flour and kinnow pomace powder blends ranged from 39.34 per cent to 74.36 per cent (Table 1). The analysis of variance (ANOVA) for expansion ratio of quadratic model (Eq. 5) is given in Table 2. The coefficient of determination $\left(\mathrm{R}^{2}\right)$ and adjusted $\mathrm{R}^{2}$ for the WSI were 0.8686 and 
0.7503, respectively. The coefficient of variation $(\mathrm{CV})$ was found to be $7.64 \%$. F value for expansion ratio was significant $(\mathrm{P}>$ 0.0022) whereas lack-of fit was not significant $(\mathrm{P}>0.8984)$.

Moisture $\left(x_{1}\right), \quad$ screw speed $\left(x_{2}\right)$ and temperature $\left(x_{\mathrm{g}}\right)$ had significant negative linear effect. WSI decreased with increase in moisture. Similar results have been reported by Kumar et al., (2010) and Ding et al., (2006) in rice based extrudates, Pathania et al., (2013) in wheat, mung-bean and rice blend, Onyango et al., (2005) in maize finger millet blend and Yogci and Gogus (2008) in rice grit-wheat flour based extrudates. Kumar et al., (2010) reported increase in WSI with elevated moisture levels whereas further increase lead to a sharp decline in carrot pomace pulse powder blended with rice flour. Increase in moisture content lead to plasticization of extruded melt thus reducing the extent of gelatinization and causing minor degradation of starch. Increasing screw speed resulted in increase in WSI. As screw speed elevated, there was a sharp increase in SME which induced high mechanical shear degrading the macromolecules and thus reducing their molecular weight resulting in synthesis of more water soluble compounds (Mezreb et al., 2003). WSI decreased with increase in temperature. Similar results were observed by Altan et al., (2008b) in tomato pomace based extruded snacks and Gutkoski and El-Dash, (1999) in extruded oats snacks. Molecular interactions between damaged starch, denatured protein and lipid components can cause an increase in molecular weight resulting in reduced formation of water soluble components (Dogan and Karwe 2003) (Altan et al., 2008b).

\section{Hardness}

Mathematical model was fitted to the experimental data using regression analysis.
Equation for hardness's predicted model in the form of coded values can be devised as:

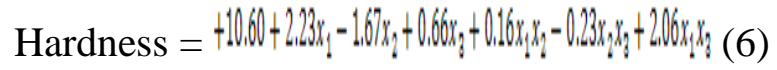

Hardness is generally refers to force required to break the extrudate sample (Singh et al., 1994; Altan et al., 2008a, 2008b). The measured hardness in extrusion cooking of rice flour and pomace powder blends ranged from $5.85 \mathrm{~N}$ to $18.23 \mathrm{~N}$ (Table 1). The analysis of variance (ANOVA) for hardness of quadratic model (Eq. 6) is given in Table 2. The values for coefficient of determination $\left(R^{2}\right)$ and adjusted $R^{2}$ values obtained were 0.9988 and 0.9970 , respectively with $0.42 \%$ of coefficient of variance. $F$ value for SME was significant $(\mathrm{P}<0.001)$ whereas lack-of fit was not significant $(\mathrm{P}>0.0817)$.

Moisture $\left(x_{1}\right)$ and temperature $\left(x_{a}\right)$ had a highly positive significant linear effect whereas screw speed $\left(x_{2}\right)$ had negative linear effect on hardness. Hardness increased with increase in moisture.

Pomace powder and spice mix present in the formulation might have absorbed excess moisture resulting in increase in hardness. Perverse to it, increasing screw speed resulted in decrease in hardness. Similar results were observed by Altan et al., (2008b) in barley flour and tomato pomace blend, $\mathrm{Wu}$ et al., (2007) in flaxseed-corn meal blend and Ding et al., (2006) in wheat extrudates. High screw speed increased the barrel temperature resulting in higher expansion and decreased hardness.

Hardness increased with increase in temperature. Similar results were observed by Altan et al., (2008b) in barley flour and tomato pomace blend, Sebio and Chang (2000) in yam flour extrudate, Yuliana et al., (2006) in starch extrudates and Keawpeng et al., (2014) in rice extrudates. 


\section{Overall acceptability}

Mathematical model was fitted to the experimental data using regression analysis. Equation for overall acceptability's predicted model in the form of coded values can be devised as:

Overall acceptability =

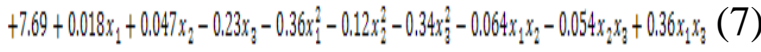

Overall acceptability score was the mean of different sensory attributes (color, texture, flavour, and taste). The measured overall acceptability of pomace based extrudates ranged from 6.16 to 7.80 (Table 1). The analysis of variance (ANOVA) for hardness of quadratic model (Eq. 7) is given in Table 2.

The values for coefficient of determination $\left(R^{2}\right)$ and adjusted $R^{2}$ values obtained were 0.9798 and 0.9616 , respectively with $1.46 \%$ of coefficient of variance. $F$ value for overall acceptability was significant $(\mathrm{P}<0.001)$ whereas lack-of fit was not significant $(\mathrm{P}>$ 0.0586 ).With increase in moisture and screw speed, sensory scores seemed to be increasing indicating a positive effect of these variables on the extrudates. Contrary to that, it was observed that overall acceptability decreased with increase in temperature.

\section{Optimization}

The optimum values for moisture content, temperature and screw speed were observed as 16 per cent, $131^{\circ} \mathrm{C}$ and $550 \mathrm{rpm}$, respectively with desirability of 0.653 out of 1.00 (Fig. 3). The variation between predicted response values and the actual response values was quite reasonable (Table 3) as it was recorded to be less than 5\%. Pomace based extruded snacks had $2.91 \%$ moisture, $9.59 \%$ protein, $2.12 \%$ fiber, $0.22 \%$ fat and $3.26 \%$ ash (Table 4). The average score was 7.63 on a 9-point hedonic scale, when the final product was subjected to consumer acceptability test.

The findings of this study demonstrate the possibility of using $2 \%$ kinnow pomace as an ingredient in making extruded products with higher preference levels for parameters of appearance, texture, flavor (taste and odour) and overall acceptability. The kinnow pomace was being used wholly in extrusion process. Addition to that, there was no effluent or waste generated during processing of pomace based expanded snacks. RSM revealed the significant effect of three primal parameters viz. feed moisture barrel temperature and screw speed, on physical properties of kinnow pomace based snacks. Within the experimental range, feed moisture was the most important factor affecting the physical properties of the extrudate. The effect of feed moisture on most of the properties of the extrudate was found to be linear. The feed moisture and screw speed had quadratic effect on hardness; the interactive effect of feed moisture and screw speed were found significant on WSI. The overall acceptability, hardness and WAI increased and ER, BD and WSI decreased with increase in moisture whereas ER, WAI and overall acceptability increased and BD, WSI and hardness decreased with the increase in screw speed. On the other hand, WAI and hardness increased while WSI, overall acceptability, $\mathrm{BD}$ and ER decreased with the increase in temperature. The SME increased with the increase in feed moisture and screw speed, whereas it decreased with the increase in temperature.

\section{References}

Altan A, Mccarthy K L and Medeni M 2008a. Twin screw extrusion of barley grape pomace. J Food Engg 89: 24-32.

Altan A, McCarthy K L and Medeni M 2008b. Evaluation of snack foods from 
barley-tomato pomace blends by extrusion processing. J Food Engg 84: 231-42.

Anderson R A, Conway H F and Griffin E L 1969. Gelatinization of corn grits by roll and extrusion cooking. Cereal Sci Today 14: 4-12.

Asare E.K.,Sefa-Dedeh S., Sakyi-Dawson E. and Afoakwa E.O., 2004. Application of response surface methodology for studying the product characteristics of extruded rice-cowpea-groundnut blends 2000 Corn bran as a fiber source in expanded snack. Lebens-Wiss. Technol. 33, 2-8.. Int. J. Food Sci. Nutr. 55, 431 439.

Asgher, M., \& Bhatti, H. N. (2012). Removal of reactive blue 19 and reactive blue 49 textile dyes by citrus waste biomass from aqueous solution: equilibrium and kinetic study. The Canadian Journal of Chemical Engineering, 90(2), 412-419.

Baik BK, Powers J and Nguyen LT (2004) Extrusion of regular and waxy barley flours for production of expanded cereals. Cereal Chem 81: 94-99.

Baladran-Quintana R.R, Barbosa-Canovas G.V., Zazueta-Morales J.J., AnzalduaMorales A. and Quintero-Ramos A., 1998. Functional and nutritional propertie of extruded whole pinto bean meal (Phaseolus vulgaris L.). J. Food Sci. 63, 113-116.

Barrett A. H. and Peleg M., 1992. Extrudate cell structure-texture relationships. J. Food Sci. 57, 1253-1257.

Case S.E., Hamann D.D., Schwartz S.J., 1992. Effect of starch gelatinization on physical properties of extruded wheat and corn based products. Cereal Chem. 69, 401-404.

Chakraborty P and Banerjee S (2009) Optimization of extrusion process for production of expanded product from green gram and rice by response surface methodology. J Scientific Industrial Res
68: $140-48$.

Chang Y.K., Silvia M.R., Gutkoski L.C., Sebio L. and Da Silvia M.A.A.P, 1998. Development of extruded snacks using jatoba (Hymenaea stigonocarpa Mart) flour and cassava starch blends. J. Sci. Food Agri. 78, 59-66.

Chevanan N., Rosentrater K.A. and Muthukumarappan Effect of DDGS, Moisture Content, and Screw Speed on Physical Properties of Extrudates in Single-Screw Extrusion. Cereal Chem. 85, 132-139.

Ding Q. B., Ainsworth P., Plunkett, A., Tucker G. and Marson H. 2006. The effect of extrusion conditions on the functional and physical properties of wheat-based expanded snacks. J. Food Eng. 73, 142-148.

Dogan H and Karwe M V (2003) Physicochemical properties of quinoa extrudates. Food Sci Technol Int Madrid 9: 101-14.

Fan, J., Mitchell J.R. and Blanchard, J.M.V. 1996. The effect of sugars on the extrusion of maize grits: The role of the glass transition in determining product density and shape. International Journal of Food Science and Technology 31: $55-65$.

Garber B.W., Hsieh F. and Huff H.E., 1998. Influence of Particle Size on the TwinScrew Extrusion of Corn Meal. Cereal Chem. 74, 656-661.

Garzón, C. G., \& Hours, R. A. (1992). Citrus waste: an alternative substrate for pectinase production in solid-state culture. Bioresource technology, 39(1), 93-95.

Gomez M H and Aguilera J M (1984) A physicochemical model for extrusion of corn starch. J Food Sci 49: 40-42.

Guha M, Ali S Z and Bhattacharya S (2006) Twin-screw extrusion of rice flour without a die: Effect of barrel temperature and screw speed on 
extrusion and extrudate characteristics. J Food Engg 32: 251-67.

Gutkoski L.C. and El-Dash A.A., 1999. Effect of extrusion process variables on physical and chemical properties of extruded oat products. Plant Food Hum. Nutr. 54, 315-325.

Hagenimana, A., Ding, X. and Fang, T. 2006. Evaluation of rice flour modified by extrusion cooking. J Cereal Sci. 43, 3846.

Hsieh F., Grenus K.M., Hu L. and Huff H.E., 1993. Twin-screw extrusion of rice flour with salt and sugar. Cereal Chem. 70: 493-498.

Jin Z, Hsieh F and Huff H E (1994) Extrusion cooking of corn meal with soy fiber, salt, and sugar. Cereal Chem 71:227-33.

Kannadhason S., Muthukumarappan K., and Rosentrater K.A., 2009. Effects of ingredients and extrusion parameters on aquafeeds containing ddgs and tapioca starch" j. aquacultu. feed sci. and nutr. 1.1: 6-21

Keawpeng, I., Charunuch, C., Roudaut, G. and Meenune, M., 2014. The optimization of extrusion condition of Phatthalung Sungyod rice extrudate: a preliminary study. Int J Food Res 21: 2299-2304.

Koksel H., Ryu G.H., Basman A., Demiralp H. and $\mathrm{Ng} \mathrm{P.K.W.,} \mathrm{2004.} \mathrm{Effects} \mathrm{of}$ extrusion variables on the properties of waxy hulless barley extrudates. Nahrung 48, 19-24.

Kumar N (2010) Development and Characterization of Extruded Product Using Carrot Pomace and Rice Flour. Int J Food Engg 6: 3754-58.

Lohrasbi, M., Pourbafrani, M., Niklasson, C., \& Taherzadeh, M. J. (2010). Process design and economic analysis of a citrus waste biorefinery with biofuels and limonene as products. Bioresource tech, 101: 7382-7388.

Malla, B. A., Rastogi, A., Sharma, R. K.,
Ishfaq, A., and Farooq, J. 2015. Kinnow madarin (Citrus nobilis lourx Citrus deliciosa tenora) fruit waste silage as potential feed for small ruminants. Veterinary world, 8(1), 19.

Mendonca S., Grossman M.V.E. and Verhé R., 2000. Corn Bran as a Fibre Source in Expanded Snacks. LWT-Food Sci. Technol. 33, 2-8.

Mercier C and Fillet P. 1975. Modification of carbohydrate component of extrusion cooking of cereal product. Cereal Chem 52: 283-97.

Mezreb K, Goullieux A, Ralanirina R and Queneudec (2003) Application of image analysis to measure screw speed influence on physical properties of corn and wheat extrudates. J Food Engg 57: 145-52.

NHB (2011) Indian Horticulture Database. National Horticulture Board, Ministry of Agriculture, Government of India, New Delhi.

Onyango et al., 2005. Digestibility and antinutrient properties of acidified and extruded maize-finger millet blend in the production of uji. LWT-Food Sci. Technol. 38, 697-707.

Pan Z, Zhang S and Jane J (1998) Effects of extrusion variables and chemicals on the properties of starch-based binders and processing conditions. Cereal Chem 75: 541-46.

Pansawat N, Jangchud K, Jangchud A, Wuttijumnong $\mathrm{P}$, Saalia $\mathrm{F} \mathrm{K}$ and Eitenmiller R R (2007) Effects of extrusion conditions on secondary extrusion variables and physical properties of fish, rice-based snacks. Lebensm Wiss u Technol 41: 632-41.

Pathania S., Singh B., Sharma S., Sharma V. and Singla S., 2013. Optimization of extrusion processing conditions for preparation of an instant grain base for use in weaning foods. Int. J. Eng. Res. Appl. 3, 1040-1049. 
Patil R T, Berrios J A G and Swansons B G (2007) Evaluation of methods for expansion properties of legume extrudates. Applied Engg Agric 23: 77783.

Report of the Joint Inspection Team on its visit to Punjab during 15-21 February, 2013 to review the progress under the National Horticulture Mission.

Ryu G H and Ng P K W (2001) Effects of selected process parameters on expansion and mechanical properties of wheat flour and whole cornmeal extrudates. Starch 53: 147-54.

Sanderson, G. R. (1981), Applications of Xanthan gum. Brit. Poly. J., 13: 71-75.

Sebio L. and Chang Y.K., 2000. Effects of selected process parameters in extrusion of yam flour (Dioscorea rotundata) on physicochemical properties of the extrudates. Mol. Nutr. Food Res. 44, 96-101.

Singh B., Hussain Z.S. and Sharma S., 2013. Response surface analysis and process optimization of twin screw extrusion cooking of potato-based snacks. J. Food Process. Preserv. 39, 270-281.

Singh R., Chatli M.K., Biswas A.K. and Sahoo J., 2011. Quality and storage stability of chicken meat patties incorporated with linseed oil. J. Food
Quality. 34, 352-362.

Tripodo, M. M., Lanuzza, F., Micali, G., Coppolino, R., \& Nucita, F. (2004). Citrus waste recovery: a new environmentally friendly procedure to obtain animal feed. Bioresource Technology, 91(2), 111-115.

Wu W., Huff H.E. and Hsieh F., 2007. Processing and properties of extruded flaxseed- corn puff. J Food Process. Pres. 31, 211-226.

Yagci S and Gogus F (2008) Development of extruded snack from food by-products: A response surface analysis. J Food Process Engg 32: 565-86.

Yeh A I and Jaw Y M (1999) Effects of feed rate and screw speed on operating characteristics and extrudate properties during single-screw extrusion cooking of rice flour. Cereal Chem 76:236-42.

Yeh, L.L., Kim, K.O., Chompreeda, P., Rimkeeree, H. and Yau, N.J.N. 1998. Comparison in use of the 9-point hedonic scale between Americans, Chinese, Koreans, and Thai. Food Qual. Prefer. 9, 413-419.

Yuliani S., Torley P.J., Bhandari B., 2006. Physical and processing characteristics of extrudates made from starch and dlimonene mixtures. Int. J. Food Sci. Technol. 41, 83-94.

\section{How to cite this article:}

Himanshu Prabhakar, Shruti Sharma, Pushpinder Singh Ranote, Baljit Singh and Savita Sharma. 2017. Concoct Citrus Waste based Extruded Snacks: Optimizing Process Conditions Using Response Surface Methodology (RSM) and Delving Extrudate Attributes. Int.J.Curr.Microbiol.App.Sci. 6(11): 189-204. doi: https://doi.org/10.20546/ijcmas.2017.611.024 